\title{
Czech Greenpeace Donors and the Barriers to their Climate-Friendly Household Behaviour
}

\author{
Jan Krajhanzl, Jan Skalík
}

\begin{abstract}
In the decades to come, global climate change poses a significant environmental, social, and economic threat. Among the various strategies that are being implemented to reduce this threat are those that focus on decreasing greenhouse gas emissions by supporting the climate-friendly behaviour of the general public. The present study is focused on Czech Greenpeace donors. These donors represent a segment of the public that, while engaged in supporting systemic policy measures in the area of climate protection, also has the potential to grow in the area of climate-friendly household behaviour. Our research is based on a sample of 504 respondents and deals with this group's climate-relevant household behaviour. In relation to Community-Based Social Marketing, we examine the potential of Greenpeace donors to behave in a climate-friendly way, and we identify the barriers that prevent them from getting involved in a broader spectrum of climate-friendly behaviour. Our analysis is informed by several significant contemporary theories of pro-environemntal behaviour. We also highlight topic areas on which to focus when encouraging Greenpeace donors to further improve their climate-friendly behaviour.
\end{abstract}

KEYWORDS Climate-friendly behaviour, support of pro-environmental behaviour, willingness to change, motivation, Community-Based Social Marketing, donor, Greenpeace

\section{Introduction}

Global climate change is considered to be one of the main environmental threats of our time (WBGU 2007; Richardson et al. 2009; UN 2009; Bergengren, Waliser and Yung 2011; Gemenne et al. 2014; IPCC 2014). In this context, most climate scientists are in agreement that a significant cause of current global climate change is human activity, particularly the production of greenhouse gases (IPCC 2014).

It is necessary to search for solutions at the macro-level of politics as well as at the micro-level of individual behaviour (Dietz et al. 2009; Dietz, Leshko and McCright 2013). The general public can become involved in climate protection through taking part in civic and political activities as well as through making changes in their household behaviour (Kent 2009, Dietz et al. 2009; Dietz, Stern and Weber 2013). It is the micro-level of household behaviour that we focus on in this study.

According to representative public opinion surveys, $80 \%$ of people living in the Czech Republic think that global warming is already happening (STEM 2009: definitely yes 33\%,

Sociálni studia. Department of Sociology FSS MU, 3/2015. S. 71-95. ISSN 1214-813X. 
more likely yes $47 \%$ ). Three quarters think that the cause of this warming is more likely human behaviour than natural processes (ibid.; definitely yes $20 \%$, more likely yes $55 \%$ ). As the survey of the CVVM (2014) shows, $67 \%$ believe that global warming is very serious $(31 \%)$ or quite serious (36\%). Eurobarometer results (TNS Opinnion \& Social 2014) indicate that in the area of household behaviour, the largest section of the Czech population has started to reduce waste and recycle (70\%), cut down on consumption of disposal items $(50 \%)$, and give preference to energy-efficient appliances when purchasing new ones (41\%). A smaller section of the population has now begun to prefer local and seasonal food (29\%), use environmentally-friendly alternatives to using a private car (22\%), and have their houses insulated $(18 \%)$. Only a tiny section of the population has limited short-haul flights (10\%), bought fuel-efficient cars $(9 \%)$, switched to an energy supplier which offers a greater share of energy from renewable sources (5\%), and installed equipment at home (like solar panels, $3 \%$ ) or bought a low-energy household (1\%).

How to support more climate-friendly behaviour among the Czech population? One way could be to design a public education campaign targeted at a segment of society that exhibits certain pro-environmental attitudes and behaviours and at the same time still has an untapped potential to participate in more pro-climate consumption behaviours. For the purposes of our research, we have chosen the donors of Greenpeace Czech Republic. They have expressed their interest in environmental protection by financially contributing to a major environmental non-governmental organization. They show their support of climate protection through mediated, macro-level focused activities, such as financial and civic support of Greenpeace goals. However, their climate-friendly household behaviour has not been investigated, and the pro-climate potential of such activities may prove to be quite strong. As Greenpeace donors are expected to be in the forefront of environmental innovations, their potential change in behavioural should also bring a significant leverage effect. Further, they are on the Greenpeace mailing list and so constitute a group that can be easily reached when it comes to providing climate education and encouraging other forms pro-environmental behaviour. Moreover, this social segment offers a particularly interesting subject for theoretical considerations of the consistency (or inconsistency) between pro-environmental attitudes and proenvironmental behaviours, as well as for investigating the barriers that interfere with the proenvironmental behaviour of the people in this segment.

The Greenpeace branch in Czechoslovakia opened in 1992. At present, Czech branch campaigns focus primarily on climate protection in relation to coal mining in the Czech Republic. They also focus on on various global topics such as reducing toxic pollution, protecting ocean flora and fauna and protecting the world's rainforests (Greenpeace Česká republika 2014a). The funding for Greenpeace activities comes predominantly from contributions by individual donors, and only a tiny fraction of it comes from other sources. According to the latest available annual report, in the calendar year 2012 Greenpeace Czech Republic was supported by contributions from 13,977 individual donors (Greenpeace Česká republika, 2014b), which represents the widest support for any environmentally oriented non-governmental organization in the country.

Greenpeace activities have also been the subject of natural science (Greenpeace International 2009; University of Exeter 2010) and social research. In the last few years, 
social science studies have been devoted to, for example, the media representation of the conflict between Greenpeace and the Shell company (Bakir 2005), the type of visual communication that Greenpeace used regarding climate change and the side effects of such communication (Doyle 2007), a comparison of how Greenpeace structured their communication of environmental problems on their websites in China, Japan, and Germany (Heinz, Cheng and Inuzuka 2007), the reasons why Greenpeace-style activism has not taken hold in Norway (Strømsnes, Selle and Grendstad 2009), and the framing of the conflict between Greenpeace and the oil company BP in the media (García 2011).

The present study deals with a topic that has not yet been investigated by either Czech or foreign researchers. Our primary research question is: What are the barriers to the climate-friendly household behaviour of the donors of Greenpeace Czech Republic? In relation to this question, we examine: What is the respondents' potential for behaving in a more climate-friendly way? Do the respondents always report the same barriers to different types of environmentally-friendly behaviour and do these barriers correspond to a particular model of pro-environmental behaviour (Ajzen 1991; Stern 2000)? How reliable are the respondents' answers when they identify the various barriers: do the reported barriers indicate a statistically significant increase or decrease in the respondents' willingness to change their behaviour? What topic areas should be highlighted in communicating with this target group about the various climate-friendly behaviours so that the public education campaign could more effectively encourage their willingness to change their behaviour?

\section{The barriers to climate-friendly behaviour}

In this study we draw on the Community-Based Social Marketing approach (McKenzieMohr and Smith 1999; McKenzie-Mohr 2011; McKenzie-Mohr, Schultz, Lee and Kotler 2012). This approach describes how to proceed when designing public education campaigns focused on encouraging pro-environmental behaviour. In the last few years, this approach has become widely accepted: today it is recommended in textbooks on the subject (Clayton and Myers 2009: 156-157; Lee and Kotler 2011), and it has been applied in supporting a broad spectrum of pro-environmental behaviour (McKenzie-Mohr, Schultz, Lee and Kotler 2012; McKenzie-Mohr and Associates 2014).

According to Community-Based Social Marketing, if our aim is to effectively encourage the public's pro-environmental behaviour, it is important to understand what prevents proenvironmental behaviour (the barriers) and what supports pro-environmental behaviour (the benefits). It is also necessary to examine the barriers and benefits of specific pro-environmental behaviours of a specific target group, so that the mapping of these barriers and benefits can then be used to design a custom-made campaign for the given situation. As this approach suggests, campaign preparation should follow these five steps: 1 . Selection of the behaviour that is the target of the campaign; 2. Identification of barriers and benefits; 3. Formulation of strategy; 4. Pilot verification of the strategy; 5. Broad-scale implementation and evaluation (McKenzieMohr and Smith 1999; McKenzie-Mohr 2011; McKenzie-Mohr, Schultz, Lee and Kotler 2012).

In this study we deal with step number 2: identifying the barriers to climate-friendly behaviour. 


\section{Methods}

The survey instrument

As part of preliminary research, two focus groups were formed and one pilot quantitative survey $(\mathrm{N}=448)$ with Greenpeace donors was conducted. The survey examined the respondents' climate-relevant household behaviour and the barriers to their climate-friendly behaviour. On the basis of these preliminary investigations, seven specific climate-relevant behaviours were identified, and the most frequently occurring barriers were categorized.

In our mapping of barriers to climate-friendly behaviour, we draw on the Community-Based Social Marketing approach (McKenzie-Mohr and Smith 1999; McKenzie-Mohr 2011; McKenzieMohr, Schultz, Lee and Kotler 2012). This approach recommends that researchers consult available scholarly sources, and we looked for insights in several influential theories of pro-environmental behaviour (Theory of Planned Behaviour - Ajzen 1991; Value-Belief-Norm - Stern 2000; Responsible Environmental Behaviour - Hungerford and Volk 1990), as well as in meta-analyses conducted in the area of environmental behaviour (Bamberg and Möser 2007). In addition, the main phase of our research, that is colleting data from the respondents among Czech Greenpeace donors, was preceded by conducting research among two focus groups. Before these meetings, we asked the 14 participants ( 9 males, 5 females; mean age 34.8 years) in the focus groups to think about sensible actions to help prevent climate change. The participants identified improvements in public transport, decrease in meat consumption, the use of natural and energy resources, and the use of energy-demanding appliances as major mitigating actions. Political activity, such as participation in demonstrations or writing letters to politicians, was also widely disscussed.

Following the Community-Based Social Marketing approach, we examine what Greenpeace donors consider to be the barriers to their climate-friendly behaviour (see Table 1). Further, we complement this approach by analyzing the reliability of the respondents' answers - whether the barriers that they have identified also indicate a significantly greater or lesser willingness to participate in more climate-friendly behaviour.

Table 1: The barriers to climate-friendly behaviour examined in this study as situated within the context of the existing key theories and meta-analyses of pro-environmental behaviour

\begin{tabular}{|l|l|}
\hline Factor & Description of the factor \\
\hline $\begin{array}{l}\text { I don't have enough information about } \\
\text { how the behaviour change would }\end{array}$ & $\begin{array}{l}\text { Lack of knowledge or lack of awareness of the behaviour's } \\
\text { consequences for the climate. Corresponds with awareness of } \\
\text { the consequences of one's behaviour (compare with Stern 2000; } \\
\text { Klöckner 2013). }\end{array}$ \\
\hline time demands & $\begin{array}{l}\text { Lack of time for the activity, which may be due to the actual } \\
\text { time demands of the activity, due to a general lack of time, } \\
\text { other priorities, or convenience. Part of a more broadly defined } \\
\text { perceived behaviour control (compare with Ajzen 1991; } \\
\text { Bamberg and Möser 2007; Klöckner 2013) which depends } \\
\text { on the perceived difficulty of the behaviour. }\end{array}$ \\
\hline financial demands & $\begin{array}{l}\text { Lack of financial means for the activity, which is due to the expense } \\
\text { of the given activity in comparison to other available activities, or } \\
\text { due to one's opportunities and personal priorities. An important } \\
\text { factor is also how the cost of the activity is distributed over time. } \\
\text { Part of a more broadly defined perceived behaviour control } \\
\text { (compare with Ajzen 1991; Bamberg and Möser 2007; Klöckner } \\
\text { 2013) which depends on the perceived difficulty of the behaviour. }\end{array}$ \\
\hline
\end{tabular}




\begin{tabular}{|c|c|}
\hline Factor & Description of the factor \\
\hline $\begin{array}{l}\text { expended energy demands } \\
\text { (effort required) }\end{array}$ & $\begin{array}{l}\text { Too much effort is required for the activity, which is influenced } \\
\text { by the difficulty of the activity in comparison with perceived } \\
\text { competencies, by priorities, and by convenience. Part of a more } \\
\text { broadly defined perceived behaviour control (compare with } \\
\text { Ajzen 1991; Bamberg and Möser 2007; Klöckner 2013) which } \\
\text { depends on the perceived difficulty of the behaviour. }\end{array}$ \\
\hline $\begin{array}{l}\text { low support and understanding from my } \\
\text { significant others }\end{array}$ & $\begin{array}{l}\text { Perceived unfavorable social norm of one's significant others. } \\
\text { Corresponds with subjective norm (compare with Ajzen 1991), } \\
\text { and social norm (compare with Bamberg and Möser 2007; } \\
\text { Klöckner 2013). }\end{array}$ \\
\hline $\begin{array}{l}\text { I don't have enough practical } \\
\text { information about how to implement } \\
\text { the change }\end{array}$ & $\begin{array}{l}\text { Lack of knowledge or skills for participating in the behaviour. } \\
\text { Corresponds with action skills (compare with Hungerford and Volk } \\
\text { 1990), influences perceived behaviour control (compare with } \\
\text { Ajzen 1991; Bamberg and Möser 2007; Klöckner 2013) }\end{array}$ \\
\hline $\begin{array}{l}\text { I don't consider climate change to } \\
\text { be a sufficient reason to change my } \\
\text { behaviour }\end{array}$ & $\begin{array}{l}\text { Perceived low threat of global climate change, possibly } \\
\text { perceived lack of its relevance in connection to behaviour } \\
\text { change. Corresponds with problem awareness (compare } \\
\text { with Bamberg and Möser 2007) and the New Environmental } \\
\text { Paradigm (compare with Stern 2000; Klöckner 2013). }\end{array}$ \\
\hline health reasons & $\begin{array}{l}\text { Reported health reasons. They influence perceived behaviour } \\
\text { control (compare with Ajzen 1991; Bamberg and Möser 2007; } \\
\text { Klöckner 2013). }\end{array}$ \\
\hline loss of satisfaction & $\begin{array}{l}\text { Negative perception of a hedonistic character, influences } \\
\text { attitude toward behaviour. Corresponds with values (compare } \\
\text { with Stern 2000; Klöckner 2013) and attitude toward behaviour } \\
\text { (compare with Ajzen 1991; Bamberg and Möser 2007). }\end{array}$ \\
\hline $\begin{array}{l}\text { I think that in this case l'm doing enough } \\
\text { for climate protection }\end{array}$ & $\begin{array}{l}\text { Low willingness to grow further in relation to climate-friendly } \\
\text { behaviour. Corresponds with behavioural intention (compare } \\
\text { with Ajzen 1991; Bamberg and Möser 2007; Klöckner 2013) } \\
\text { and personal norm (compare with Stern 2000). }\end{array}$ \\
\hline $\begin{array}{l}\text { It's not possible to further improve } \\
\text { the behaviour in any way (no flying, } \\
\text { recycling of all waste, etc.) }\end{array}$ & $\begin{array}{l}\text { Reported climate-friendly behaviour. Given the use of self- } \\
\text { reports, the risk of social stylization has been lowered by } \\
\text { specifying the maximum degree of climate-friendly behaviour. }\end{array}$ \\
\hline
\end{tabular}

The whole questionnaire, of which only the key section dealing with barriers to climatefriendly behaviour is being analyzed in this study, also incorporates other concepts and sociodemographic questions.

\section{Sample composition and data collection}

Data collection was conducted using the CASI method and the online application SurveyMonkey during the period of 20 September to 9 October 2011. The questionnaire was sent out repeatedly to all of the email contacts in the Greenpeace Czech Republic database, which included both their current and former individual donors. The questionnaire informed the respondents that the survey was being conducted in order to improve our theoretical and practical understanding of the issues. No material reward was offered to encourage participation. From the total number of 9,355 contacts, 650 people started to fill in the questionnaire (response rate $6.9 \%$ ). During the process of checking and cleaning 
the data, the answers of 146 respondents were deleted because they had answered less than half of the questions in the questionnaire. Therefore, the research results are based on data from the 504 respondents (response rate 5.4\%) who answered all the questions in the section of the questionnaire dealing with behavioural barriers. Finally, 477 respondents completed the whole questionnaire. In the survey sample $62 \%$ of respondents are females and $38 \%$ males; $55 \%$ of respondents are current GP donors. The socio-demographic composition of the sample is summarized in tables 2-5. The data about the Czech population come from the Czech Statistical Office (2011).

Table 2: Sample Composition

\begin{tabular}{|l|c|c|c|c|c|}
\hline & Mean & Median & Minimum & Maximum & Czech Rep. \\
\hline Age (in years) & 34 & 32 & 16 & 74 & 41 \\
\hline Number of children & 1.8 & 2 & 1 & 8 & 1.7 \\
\hline $\begin{array}{l}\text { Average size of place of residence } \\
\text { (number of inhabitants) }\end{array}$ & 401,767 & 32,500 & 250 & $1,268,000$ & $/$ \\
\hline Average income (CZK) & 19,896 & 17,500 & 0 & 81,000 & 18,824 \\
\hline
\end{tabular}

Table 3: Sample composition per highest level of completed education

\begin{tabular}{|l|c|c|}
\hline & Sample & Czech Rep. \\
\hline Primary & $2.1 \%$ & $16.6 \%$ \\
\hline Secondary (trade) & $3.1 \%$ & $35.4 \%$ \\
\hline Secondary (academic) & $35.0 \%$ & $34.2 \%$ \\
\hline College & $3.8 \%$ & \multirow{2}{*}{} \\
\cline { 1 - 2 } Bachelor's degree & $16.4 \%$ & \multirow{2}{*}{$13.7 \%$} \\
\hline Master's degree & $30.6 \%$ & \\
\hline Higher academic degree & $9.0 \%$ & \\
\hline
\end{tabular}

Table 4: Sample composition per marital status

\begin{tabular}{|l|c|c|}
\hline & Sample & Czech Rep. \\
\hline Single & $51.7 \%$ & $31.6 \%$ \\
\hline Married & $37.5 \%$ & $56.3 \%$ \\
\hline Divorced & $9.5 \%$ & $9.1 \%$ \\
\hline Widowed & $1.3 \%$ & $2.9 \%$ \\
\hline
\end{tabular}


Table 5: Sample composition per field of highest completed education

\begin{tabular}{|l|c|}
\hline Technical & $23.1 \%$ \\
\hline Economic & $17.0 \%$ \\
\hline Social Sciences & $15.5 \%$ \\
\hline Natural Sciences & $12.2 \%$ \\
\hline Other & $8.8 \%$ \\
\hline Pedagogic & $7.3 \%$ \\
\hline Art & $6.7 \%$ \\
\hline Medical & $5.0 \%$ \\
\hline Helping professions & $2.1 \%$ \\
\hline Other / No answer & $2.3 \%$ \\
\hline
\end{tabular}

The collected data were compared to the full socio-demographic profile of the survey population. For this purpose, we used the comprehensive information in the database of Greenpeace donors which includes information regarding the duration of support for the organization, place of residence and the donor's gender (influential to pro-environmental attitudes as proven by numerous research; see Mobley 2013). Based on a comparison of this information with the information reported in the questionnaire, we were able to determine the relative weight of the individual respondents. Since the differences between the research population and the sample turned out to be fairly small, the weight for the given data varied between 0.79 and 1.33 (see table 6).

Table 6: Comparison of the composition of the population and the research sample

\begin{tabular}{|l|c|c|c|c|c|}
\hline \multirow{2}{*}{} & \multicolumn{2}{|c|}{ GP Population } & \multicolumn{2}{c|}{ GP Sample } & \multicolumn{1}{c|}{$\begin{array}{c}\text { Relative weight } \\
\text { (\% pop./\% sample) }\end{array}$} \\
\cline { 2 - 6 } & $\mathbf{N}$ & Share & $\mathbf{N}$ & Share & 0.92 \\
\hline Former Donors & 3916 & $42 \%$ & 217 & $45 \%$ & 1.07 \\
\hline Male & 5439 & $58 \%$ & 260 & $55 \%$ & 1.16 \\
\hline Female & 4178 & $45 \%$ & 183 & $38 \%$ & 0.90 \\
\hline More than 700,000 inhabitants & 5177 & $55 \%$ & 294 & $62 \%$ & 1.07 \\
\hline $130,000-700,000$ inhabitants & 1083 & $12 \%$ & 54 & $11 \%$ & 1.02 \\
\hline Fewer than 130,000 inhabitants & 5259 & $56 \%$ & 280 & $59 \%$ & 0.96 \\
\hline Not Reported & 0 & & 27 & & \\
\hline Total & 9355 & & 504 & & \\
\hline
\end{tabular}




\section{Statistical Analyses}

Given the pro-environmental profile of the respondents, it could be expected that the data would not have a parametric distribution. This premise was tested and confirmed for the individual variables with the use of the Kolmogorov-Smirnov test with Lilliefors Significance Correction, resulting in $\mathrm{p}$ value $=0.000$. The appropriateness of nonparametric tests for all the analyses was also supported by the use of graphic visualization of the data.

The research included seven selected climate-relevant household behaviours. In relation to each of these behaviours, the respondents were asked which of the eleven barriers prevent them from behaving in a climate-friendly way (these barriers were the same in all the questions). With each of the seven behaviours, the respondents were allowed to tick as many of the eleven possible barriers as applied. If the respondents reported that in a particular case they behave as climate-friendly as possible (for instance, they do not eat meat, or they do not commute short distances by car), they were not supposed to mark any barriers to their climate-friendly behaviour for that case. The answers collected from respondents who had not understood this were deleted in the process of data preparation. In the next question, the respondents were asked about their level of willingness to change any of the seven selected behaviours to make it more climate-friendly.

The results are summarized below in tables 7-16. Usually, Community-Based Social Marketing is based on a simple self-reported identification of barriers by respondents. We have expanded this approach, and thus, apart from the percentage of the individual barriers that were reported, the tables also include a comparison of how willing respondents who reported a given barrier were to change their behaviour with those who did not report the barrier. With respect to the nonparametric data distribution, the difference between these two groups was measured with the use of the Mann Whitney U test. Further, the tables include the $\mathrm{Z}$ value of the Mann Whitney $\mathrm{U}$ test, and, due to the absence of a directional hypothesis in the comparison of the groups, also 2-tailed p-values. We regard values at a significance level of $95 \%$ to be significant, that is p values lower than 0.05 . The last column in the table represents the value of the effect which was calculated as Cohen's D (Cohen 2013). The effect can be regarded to have high significance if it has reached a value of 0.8 , medium significance if it is somewhere between 0.5 and 0.8 , and low significance if at between 0.2 and 0.5 (Lenth 2001).

With a fairly large number of applied statistical tests, it is important to consider the increase of probability of the first type error. At the $95 \%$ significance level we can expect that in five out of every hundred tests performed the significant $\mathrm{p}$ value will be purely accidental. However, given the explorative character of our study, applying the Bonferonni correction for multiple tests would radically lower the significance level. Therefore we note this methodological feature of our research at the start, but we have chosen not to apply the Bonferonni correction before our interpretation of the results. 


\section{Results}

Table 7: Cumulative answers: Are you willing to consider . . .

\begin{tabular}{|c|c|c|c|c|c|c|c|c|c|c|}
\hline & Mean & $\begin{array}{l}\text { Std. } \\
\text { Dev. }\end{array}$ & $\begin{array}{c}1-\text { No, } \\
\text { not at } \\
\text { all } \\
(\%)\end{array}$ & $\begin{array}{c}2 \\
(\%)\end{array}$ & $\begin{array}{c}3 \\
(\%)\end{array}$ & $\begin{array}{c}4 \\
(\%) \\
\end{array}$ & $\begin{array}{c}5 \\
(\%) \\
\end{array}$ & $\begin{array}{c}6 \\
(\%)\end{array}$ & $\begin{array}{c}7-1 \text { 'm } \\
\text { determined } \\
\text { to change } \\
\text { this behaviour } \\
(\%) \\
\end{array}$ & $\begin{array}{c}\text { I'm } \\
\text { already } \\
\text { doing the } \\
\text { maximum } \\
(\%) \\
\end{array}$ \\
\hline $\begin{array}{l}\text { limiting your } \\
\text { purchases } \\
\text { of tropical fruit } \\
\text { (bananas, } \\
\text { oranges, kiwi, } \\
\text { and other)? }\end{array}$ & 4.30 & 1.883 & 7.9 & 13.1 & 9.9 & 10.8 & 16.0 & 20.6 & 9.7 & 11.9 \\
\hline $\begin{array}{l}\text { acquiring more } \\
\text { energy-efficient } \\
\text { household } \\
\text { appliances? }\end{array}$ & 5.09 & 1.686 & 3.4 & 3.3 & 3.9 & 6.8 & 12.8 & 19.2 & 12.2 & 38.4 \\
\hline $\begin{array}{l}\text { recycling more } \\
\text { types of waste } \\
\text { than you have } \\
\text { so far? }\end{array}$ & 5.23 & 1.686 & 3.1 & 2.6 & 3.4 & 7.1 & 12.8 & 15.1 & 16.6 & 39.3 \\
\hline $\begin{array}{l}\text { keeping the room } \\
\text { temperature in } \\
\text { your household } \\
\text { in winter at } 20^{\circ} \mathrm{C} \\
\text { or lower? }\end{array}$ & 3.29 & 1.909 & 12.6 & 12.7 & 8.1 & 7.2 & 6.5 & 6.6 & 3.6 & 42.6 \\
\hline $\begin{array}{l}\text { minimizing plane } \\
\text { travel in your free } \\
\text { time? }\end{array}$ & 4.03 & 2.046 & 4.7 & 5.5 & 2.4 & 5.8 & 3.0 & 6.4 & 4.2 & 68.0 \\
\hline $\begin{array}{l}\text { limiting short- } \\
\text { distance } \\
\text { commuting by car } \\
\text { (up to } 15 \mathrm{~km} \text { )? }\end{array}$ & 4.11 & 2.049 & 9.4 & 5.7 & 6.4 & 7.3 & 8.9 & 10.1 & 7.7 & 44.5 \\
\hline $\begin{array}{l}\text { limiting your } \\
\text { consumption } \\
\text { of meat? }\end{array}$ & 3.88 & 2.060 & 13.5 & 13.9 & 8.5 & 12.2 & 9.7 & 12.0 & 11.1 & 19.1 \\
\hline
\end{tabular}

It will become clear from further results that each behaviour, as reported by the respondents, contains its own particular composition of barriers which prevent the various climate-friendly behaviours from being adopted. But what general findings can be drawn from a comprehensive summary of the results?

Most of the donors report that they do not currently travel by plane in their free time (68\%), they do not use a car for short-distance commuting $(44.5 \%)$, and they keep the room temperature in their household in winter at $20{ }^{\circ} \mathrm{C}$ or lower $(42.6 \%)$. However, the comprehensive results indicate that a portion of current and former Greenpeace donors does have a certain untapped potential for growth in their climate-friendly behaviour.

Which behaviours exhibit the highest potential to become more climate-friendly? When we put together the respondents' positive expressions of their willingness to change a particular behaviour (the percentages at points 5, 6, and 7 of the scale), we can see that most of the 
donors show willingness to limit thier purchasing of tropical fruit (46.4\%), to recycle more types of waste (44.5\%), and to acquire more energy-efficient household appliances (44.2\%). On the other hand, efforts to motivate the donors to lower the room temperature in their household in winter may impact only $19.3 \%$ of them.

Table 8: Correlation of the level of willingness to consider changing a behaviour with the activation of barriers to the seven examined behaviours - summary data

\begin{tabular}{|l|c|c|c|}
\hline $\begin{array}{l}\text { What prevents the respondents from changing their } \\
\text { behaviour to make it more climate-friendly? (Summary } \\
\text { of the barriers to the seven selected behaviours) }\end{array}$ & $\begin{array}{c}\text { Occurrence } \\
\text { (N=292) }\end{array}$ & $\begin{array}{c}\text { Correlation } \\
\text { Coefficient } \\
\text { (Spearman's rho) }\end{array}$ & $\begin{array}{c}\text { Sig. } \\
\text { (2-tailed) }\end{array}$ \\
\hline loss of satisfaction & $26.3 \%$ & -0.40 & 0.00 \\
\hline $\begin{array}{l}\text { I think that in this case I'm doing enough for } \\
\text { climate protection }\end{array}$ & $21.2 \%$ & 0.03 & 0.61 \\
\hline $\begin{array}{l}\text { I don't have enough practical information about } \\
\text { how to implement the change }\end{array}$ & $12.7 \%$ & 0.01 \\
\hline time demands & $12.5 \%$ & -0.24 & $\mathbf{0 . 0 0}$ \\
\hline $\begin{array}{l}\text { I don't have enough information about how the } \\
\text { behaviour change would contribute to climate } \\
\text { protection }\end{array}$ & $12.2 \%$ & -0.12 & $\mathbf{0 . 0 4}$ \\
\hline financial demands & $9.0 \%$ & 0.00 & 0.96 \\
\hline expended energy demands (effort required) & $8.0 \%$ & -0.19 & $\mathbf{0 . 0 0}$ \\
\hline $\begin{array}{l}\text { low support and understanding from my significant } \\
\text { others }\end{array}$ & $7.4 \%$ & 0.03 & 0.56 \\
\hline health reasons & $6.9 \%$ & -0.20 & -0.29 \\
\hline $\begin{array}{l}\text { I don't consider climate change to be a sufficient } \\
\text { reason to change my behaviour }\end{array}$ & $2.6 \%$ & $\mathbf{0 . 0 0}$ \\
\hline
\end{tabular}

Note: In bold are cited significant values $-\mathrm{p}=0.05$.

The correlation between the indicated barriers and the reported willingness to consider changing one's behaviour is also worth mentioning. This correlation is important in connection to public education campaigns that focus generally on climate-friendly behaviour: it is advisable to look for ways to remove or lower these particular barriers. As Table 8 shows, the respondents' willingness to consider changing their behaviour significantly decreases when it comes to barriers such as loss of satisfaction (Spearman's rho $=-0.40$; occurrence $=26.3 \%$ ), the belief that climate change is not a sufficient reason to change one's behaviour $(-0.29$; $2.6 \%)$, and time demands $(-0.24 ; 12.5 \%)$. In slight correlation, willingness also decreases when it comes to health reasons $(-0.20 ; 6.9 \%)$, expended energy demands or effort required $(-0.19 ; 8.0 \%)$, and lack of information about how the behavioural change would contribute to climate protection $(-0.12 ; 12.2 \%)$. On the other hand, those who lack practical information about how to implement the change $(0.14 ; 12.7 \%)$ somewhat more frequently consider changing their behaviour.

Table 9 presents the relative frequencies of the particular barriers to the various behaviours. If we first look at the barriers in bold, that is those that influenced the respondents' 
willingness to change or improve their behaviour, it becomes clear that these barriers were often connected to loss of satisfaction, with the respondents' belief that in this case they are doing enough for climate protection, and with the opinion that climate change is not a sufficient reason to change their behaviour.

Table 9: Relative frequencies of the barriers in the seven selected behaviours

\begin{tabular}{|c|c|c|c|c|c|c|c|}
\hline & \multicolumn{7}{|c|}{ What prevents you from ... (occurrence of "yes" responses; $N=504$ ) } \\
\hline & $\begin{array}{l}\text { limiting your } \\
\text { purchases of } \\
\text { tropical fruit } \\
\text { (bananas, } \\
\text { oranges, kiwi, } \\
\text { and other)? }\end{array}$ & $\begin{array}{l}\text { limiting your } \\
\text { consumption of } \\
\text { meat? }\end{array}$ & $\begin{array}{l}\text { acquiring } \\
\text { more energy- } \\
\text { efficient } \\
\text { household } \\
\text { appliances? }\end{array}$ & $\begin{array}{c}\text { recycling more } \\
\text { types of waste } \\
\text { than you have } \\
\text { so far? }\end{array}$ & $\begin{array}{l}\text { keeping } \\
\text { the room } \\
\text { temperature in } \\
\text { your household } \\
\text { in winter at } 20 \\
{ }^{\circ} \mathrm{C} \text { or lower? }\end{array}$ & $\begin{array}{l}\text { minimizing } \\
\text { plane travel } \\
\text { in your free } \\
\text { time? }\end{array}$ & $\begin{array}{l}\text { limiting short- } \\
\text { distance } \\
\text { commuting by } \\
\text { car (up to } 15 \\
\text { km)? }\end{array}$ \\
\hline loss of satisfaction & $45.1 \%$ & $42.2 \%$ & $6.3 \%$ & / & $33.4 \%$ & $13.6 \%$ & $6.0 \%$ \\
\hline health reasons & $10.3 \%$ & $12.9 \%$ & / & $0.4 \%$ & $17.1 \%$ & $0.8 \%$ & $3.8 \%$ \\
\hline $\begin{array}{l}\text { I don't consider } \\
\text { climate change } \\
\text { to be a sufficient } \\
\text { reason to change } \\
\text { my behaviour }\end{array}$ & $5.5 \%$ & $4.6 \%$ & $1.7 \%$ & $0.5 \%$ & $1.5 \%$ & $1.4 \%$ & $1.3 \%$ \\
\hline $\begin{array}{l}\text { expended energy } \\
\text { demands (effort } \\
\text { required) }\end{array}$ & $4.5 \%$ & $4.5 \%$ & $6.1 \%$ & $11.8 \%$ & $1.3 \%$ & $4.2 \%$ & $15.4 \%$ \\
\hline financial demands & $7.8 \%$ & $5.7 \%$ & $37.9 \%$ & $0.6 \%$ & $1.0 \%$ & $4.7 \%$ & $4.0 \%$ \\
\hline time demands & $5.8 \%$ & $4.7 \%$ & $5.7 \%$ & $13.4 \%$ & $0.9 \%$ & $14.8 \%$ & $34.0 \%$ \\
\hline $\begin{array}{l}\text { I think that in this } \\
\text { case I'm doing } \\
\text { enough for climate } \\
\text { protection }\end{array}$ & $18.8 \%$ & $32.4 \%$ & $24.0 \%$ & $31.1 \%$ & $11.9 \%$ & $10.7 \%$ & $18.8 \%$ \\
\hline $\begin{array}{l}\text { low support and } \\
\text { understanding } \\
\text { from my significant } \\
\text { others }\end{array}$ & $7.0 \%$ & $10.7 \%$ & $5.2 \%$ & $8.0 \%$ & $13.5 \%$ & $1.1 \%$ & $4.3 \%$ \\
\hline $\begin{array}{l}\text { I don't have } \\
\text { enough practical } \\
\text { information about } \\
\text { how to implement } \\
\text { the change }\end{array}$ & $29.3 \%$ & $11.8 \%$ & $11.5 \%$ & $25.4 \%$ & $7.4 \%$ & $1.2 \%$ & $3.4 \%$ \\
\hline $\begin{array}{l}\text { I don't have } \\
\text { enough information } \\
\text { about how the } \\
\text { behaviour change } \\
\text { would contribute to } \\
\text { climate protection }\end{array}$ & $46.7 \%$ & $16.0 \%$ & $7.3 \%$ & $3.2 \%$ & $7.4 \%$ & $1.3 \%$ & $0.6 \%$ \\
\hline $\begin{array}{l}\text { I'm already doing } \\
\text { the maximum }\end{array}$ & $11.9 \%$ & $19.1 \%$ & $38.4 \%$ & $39.3 \%$ & $42.6 \%$ & $68.0 \%$ & $44.5 \%$ \\
\hline
\end{tabular}

Note: In bold are cited relative frequencies in which the given barrier significantly $(\mathrm{p}=0.05)$ influenced the willingness to change behaviour, with the effect size at least 0.3 . 
It is evident that the composition of the identified barriers significantly differs with each behaviour. For instance, the perceived difficulty (the effort required) of the behaviour significantly correlates with the willingness to acquire more energy-efficient appliances and to limit short-distance commuting by car. The respondents are also kept from limiting their short-distance commuting by car and from recycling more types of waste by their concerns over time demands. Health reasons play a role when considering lowering room temperature and limiting meat consumption. The support and understanding of one's significant others impact the respondents' willingness to change their eating habits - that is their consumption of meat and tropical fruit.

\section{Limiting Purchases of Tropical Fruit}

Table 10: Barriers and the willingness to consider limiting one's purchases of tropical fruit

\begin{tabular}{|c|c|c|c|c|c|c|c|c|c|}
\hline \multirow{2}{*}{$\begin{array}{l}\text { What prevents you from limiting } \\
\text { your purchases of tropical fruit } \\
\text { (bananas, oranges, kiwi, and } \\
\text { other)? [1=Yes; } 0=\mathrm{No}]\end{array}$} & \multirow{2}{*}{$\begin{array}{l}\mathrm{N}=504 \\
\text { Share } \\
\text { (Yes) }\end{array}$} & \multirow{2}{*}{$\begin{array}{l}\mathrm{N}=445 \\
\text { Share } \\
\text { (Yes) }\end{array}$} & \multicolumn{2}{|c|}{ Yes } & \multicolumn{2}{|c|}{ No } & \multicolumn{3}{|c|}{ Mann-Whitney U } \\
\hline & & & Mean & $\begin{array}{l}\text { Std. } \\
\text { Dev. }\end{array}$ & Mean & $\begin{array}{l}\text { Std. } \\
\text { Dev. }\end{array}$ & Z & $\begin{array}{l}\text { As. Sig. } \\
\text { (2-tailed) }\end{array}$ & $\begin{array}{l}\text { Effect } \\
\text { Size } \\
\text { (d) }\end{array}$ \\
\hline $\begin{array}{l}\text { I don't have enough } \\
\text { information about how limiting } \\
\text { my purchases of tropical fruit } \\
\text { would contribute to climate } \\
\text { protection }\end{array}$ & $46.7 \%$ & $53.0 \%$ & 4.11 & 1.752 & 4.52 & 2.001 & -2.827 & 0.005 & -0.22 \\
\hline $\begin{array}{l}\text { I like tropical fruit } \\
\text { (loss of satisfaction) }\end{array}$ & $45.1 \%$ & $51.2 \%$ & 3.73 & 1.799 & 4.92 & 1.779 & -6.583 & 0.000 & -0.67 \\
\hline $\begin{array}{l}\text { I don't have enough practical } \\
\text { information about how to } \\
\text { replace tropical fruit in my diet }\end{array}$ & $29.3 \%$ & $33.3 \%$ & 4.40 & 1.788 & 4.25 & 1.930 & -0.209 & 0.835 & 0.08 \\
\hline $\begin{array}{l}\text { I think that in this case l'm } \\
\text { doing enough for climate } \\
\text { protection }\end{array}$ & $18.8 \%$ & $21.3 \%$ & 5.26 & 1.746 & 4.05 & 7.839 & -5.994 & 0.000 & 0.17 \\
\hline health reasons & $10.3 \%$ & $11.7 \%$ & 3.80 & 2.072 & 4.36 & 1.852 & -1.743 & 0.081 & -0.30 \\
\hline financial demands & $7.8 \%$ & $8.9 \%$ & 4.12 & 1.518 & 4.32 & 1.918 & -1.130 & 0.259 & -0.11 \\
\hline $\begin{array}{l}\text { low support and } \\
\text { understanding from my } \\
\text { significant others }\end{array}$ & $7.0 \%$ & $8.0 \%$ & 5.31 & 1.436 & 4.21 & 1.893 & -3.107 & 0.002 & 0.59 \\
\hline time demands & $5.8 \%$ & $6.6 \%$ & 4.73 & 1.588 & 4.27 & 1.901 & -0.930 & 0.353 & 0.24 \\
\hline $\begin{array}{l}\text { I don't consider climate } \\
\text { change to be a sufficient } \\
\text { reason to change my } \\
\text { behaviour }\end{array}$ & $5.5 \%$ & $6.2 \%$ & 2.51 & 1.793 & 4.43 & 1.825 & -4.597 & 0.000 & -1.12 \\
\hline $\begin{array}{l}\text { expended energy demands } \\
\text { (effort required) }\end{array}$ & $4.5 \%$ & $5.2 \%$ & 4.13 & 1.909 & 4.31 & 1.884 & -0.393 & 0.694 & -0.10 \\
\hline $\begin{array}{l}\text { I don't purchase any tropical } \\
\text { fruit }\end{array}$ & $11.9 \%$ & / & I & I & I & I & / & I & / \\
\hline
\end{tabular}

Note: First two columns represent shares of positive answers when the reported non-participation in the respective behaviour is included or excluded from the base. In bold are cited significant values $-\mathrm{p}=0.05$. 
On the other hand, the results show that Greenpeace donors do not internally differ in their willingness to change their behaviour due to perceived behavioural barriers such as financial demands, lack of practical information, and lack of information about how the behavioural change would contribute to climate protection. The donors are willing to change, but non-targeted campains don't encourage them enough. This finding confirms the common perception that campaigns which focus only on spreading non-targeted information fail to effectively motivate changes in behaviour (Bostrom 2013; Römmele 2002).

A negative value of the effect size indicates the barriers that are significantly connected to the respondents' lower willingness to change particular behaviours. The data results on limiting purchases of tropical fruit show that $46.7 \%$ of respondents have a lack of information about how limiting their purchases would contribute to climate protection, $45.1 \%$ experience a loss of satisfaction, and $5.5 \%$ hold the opinion that climate change is not a sufficient reason to change their behaviour. Here the difference between those who have reported this barrier and those who have not is the largest.

However, it is also possible to look at these results from another perspective: if a public education campaign were to succeed in convincing the substantial $45.1 \%$ of donors that local and seasonal fruit and vegetables can also offer a satisfying gourmet experience, for some of them this barrier would probably disappear and more willingness to change their behaviour would result. In a similar way, the $46.7 \%$ of donors who do not have sufficient information about how limiting purchases of tropical fruit contributes to climate protection may benefit from a campaign that would try to explain the connection between the growing and exporting of tropical fruit and vegetables on the one hand and climate change on the other hand. This explanation would probably also be beneficial for the $5.7 \%$ of donors who are of the opinion that climate change is not a sufficient reason to change their behaviour.

Further, we should mention the respondents who express a stronger willingness to limit their purchases of tropical fruit, but who feel prevented from doing so by the lack of support and understanding of their significant others $(7.0 \%)$. In this case, it is important for a campaign to work with the social norm, encourage the donors in nonconformist behaviour and offer them tips on how to communicate with others about their difference preferences. A stronger willingness to change their behaviour is also indicated by the $18.8 \%$ of donors who believe that in this case they are doing enough for climate protection. In regards to this relatively large group, it may be worth suggesting to them that they could in fact be doing more in this regard, since the difference between the respondents who reported this barrier and those who did not, as expressed in Cohen's D, is very small.

\section{Limiting Meat Consumption}

Our analysis of the barriers that prevent the respondents from limiting their consumption of meat has brought several significant findings. The largest difference in the willingness to limit meat consumption is between those who like meat and those who do not. If a public education campaign were to succeed in suggesting that vegetarian or vegan meals can offer a satisfying gourmet experience, a space would open up for a certain decrease in meat consumption among this $42.2 \%$ of the survey population. 
Table 11: Barriers and the willingness to consider limiting one's consumption of meat

\begin{tabular}{|c|c|c|c|c|c|c|c|c|c|}
\hline \multirow{2}{*}{$\begin{array}{l}\text { What prevents you from limiting } \\
\text { your consumption of meat? } \\
{[1=\text { Yes; } 0=\text { No] }}\end{array}$} & \multirow{2}{*}{$\begin{array}{l}\mathrm{N}=504 \\
\text { Share } \\
\text { (Yes) }\end{array}$} & \multirow{2}{*}{$\begin{array}{l}\mathrm{N}=408 \\
\text { Share } \\
\text { (Yes) }\end{array}$} & \multicolumn{2}{|c|}{ Yes } & \multicolumn{2}{|c|}{ No } & \multicolumn{3}{|c|}{ Mann-Whitney U } \\
\hline & & & Mean & $\begin{array}{l}\text { Std. } \\
\text { Dev. }\end{array}$ & Mean & $\begin{array}{l}\text { Std. } \\
\text { Dev. }\end{array}$ & Z & $\begin{array}{l}\text { As. Sig. } \\
\text { (2-tailed) }\end{array}$ & $\begin{array}{l}\text { Effect } \\
\text { Size } \\
\text { (d) }\end{array}$ \\
\hline I like meat (loss of satisfaction) & $42.2 \%$ & $52.2 \%$ & 3.01 & 1.796 & 4.99 & 1.831 & -9.013 & 0.000 & -1.09 \\
\hline $\begin{array}{l}\text { I think that in this case I'm } \\
\text { doing enough for climate } \\
\text { protection }\end{array}$ & $32.4 \%$ & $40.0 \%$ & 4.58 & 1.981 & 3.48 & 2.000 & -4.600 & 0.000 & 0.55 \\
\hline $\begin{array}{l}\text { I don't have enough } \\
\text { information about how limiting } \\
\text { my consumption of meat } \\
\text { would contribute to climate } \\
\text { protection }\end{array}$ & $16.0 \%$ & $19.8 \%$ & 3.57 & 1.859 & 3.96 & 2.104 & -1.424 & 0.154 & -0.19 \\
\hline health reasons & $12.9 \%$ & $15.9 \%$ & 3.19 & 2.059 & 4.02 & 2.035 & -2.866 & 0.004 & -0.41 \\
\hline $\begin{array}{l}\text { I don't have enough practical } \\
\text { information about how to } \\
\text { replace meat in my diet }\end{array}$ & $11.8 \%$ & $14.6 \%$ & 4.08 & 1.828 & 3.84 & 2.099 & -0.688 & 0.492 & 0.12 \\
\hline $\begin{array}{l}\text { low support and understanding } \\
\text { from my significant others }\end{array}$ & $10.7 \%$ & $13.2 \%$ & 4.92 & 1.835 & 3.71 & 2.047 & -3.834 & 0.000 & 0.60 \\
\hline financial demands & $5.7 \%$ & $7.0 \%$ & 4.11 & 2.191 & 3.86 & 2.052 & -0.384 & 0.701 & 0.12 \\
\hline time demands & $4.7 \%$ & $5.8 \%$ & 4.60 & 1.891 & 3.83 & 2.064 & -1.455 & 0.146 & 0.38 \\
\hline $\begin{array}{l}\text { I don't consider climate change } \\
\text { to be a sufficient reason to } \\
\text { change my behaviour }\end{array}$ & $4.6 \%$ & $5.7 \%$ & 2.49 & 1.856 & 3.97 & 2.042 & -3.136 & 0.002 & -0.73 \\
\hline $\begin{array}{l}\text { expended energy demands } \\
\text { (effort required) }\end{array}$ & $4.5 \%$ & $5.6 \%$ & 3.97 & 2.073 & 3.87 & 2.060 & -0.097 & 0.923 & 0.05 \\
\hline I don't eat meat & $19.1 \%$ & / & / & / & / & / & / & / & / \\
\hline
\end{tabular}

Note: First two columns represent shares of positive answers when the reported non-participation in the respective behaviour is included or excluded from the base. In bold are cited significant values $-\mathrm{p}=0.05$.

Insufficient information about how meat consumption and climate change are connected was reported by $16.0 \%$ of the respondents. Nevertheless, their willingness to limit their meat consumption is neither much lower nor much higher than the willingness of those who have not reported this particular barrier. Therefore, it can be assumed that a generally-focused public education campaign would not be very effective in reaching this particular social segment. However, such a campaign could have an appreciable influence on the $4.6 \%$ of donors who do not consider climate change to be a sufficient reason to change their behaviour. It would also be important to provide encouragement and inspirational examples to the $10.7 \%$ who are willing to consider limiting their meat consumption, but who perceive the barrier that prevents them from doing so to be the lack of adequate support and understanding of their significant others. The $12.9 \%$ who express health concerns related to limiting meat consumption would probably be resistant to attempts at persuasion. Just as with the other behaviours, it is 
important to work with the $32.4 \%$ who are of the opinion that they are doing enough in this area, but simultaneously report stronger willingness to change their behaviour.

\section{Acquiring More Energy-Efficient Household Appliances}

Table 12: Barriers and the willingness to consider acquiring more energy-efficient household appliances

\begin{tabular}{|c|c|c|c|c|c|c|c|c|c|}
\hline \multicolumn{10}{|c|}{$\begin{array}{l}\text { Are you willing to consider acquiring more energy-efficient household appliances? [1=No, not at all; } 7=\text { ='m } \\
\text { determined to change this behaviour; Mean=5.09; } \mathrm{N}=278 \text { ] }\end{array}$} \\
\hline \multirow{2}{*}{$\begin{array}{l}\text { What prevents you from } \\
\text { acquiring more energy-efficient } \\
\text { household appliances? [ } 1=\text { Yes; } \\
0=\text { No] }\end{array}$} & \multirow{2}{*}{$\begin{array}{l}\mathrm{N}=504 \\
\begin{array}{l}\text { Share } \\
\text { (Yes) }\end{array}\end{array}$} & \multirow{2}{*}{$\begin{array}{l}\mathrm{N}=311 \\
\begin{array}{l}\text { Share } \\
\text { (Yes) }\end{array}\end{array}$} & \multicolumn{2}{|c|}{ Yes } & \multicolumn{2}{|c|}{ No } & \multicolumn{3}{|c|}{ Mann-Whitney U } \\
\hline & & & Mean & $\begin{array}{l}\text { Std. } \\
\text { Dev. }\end{array}$ & Mean & $\begin{array}{l}\text { Std. } \\
\text { Dev. }\end{array}$ & $\mathbf{z}$ & $\begin{array}{l}\text { As. Sig. } \\
\text { (2-tailed) }\end{array}$ & $\begin{array}{l}\text { Effect } \\
\text { Size } \\
\text { (d) }\end{array}$ \\
\hline financial demands & $37.9 \%$ & $61.5 \%$ & 5.09 & 1.567 & 5.10 & 1.895 & -0.789 & 0.430 & -0.01 \\
\hline $\begin{array}{l}\text { I think that in this case l'm doing } \\
\text { enough for climate protection }\end{array}$ & $24.0 \%$ & $38.9 \%$ & 5.00 & 2.037 & 5.14 & 1.447 & -0.658 & 0.511 & -0.09 \\
\hline $\begin{array}{l}\text { I don't have enough practical } \\
\text { information about how to find } \\
\text { and choose more energy- } \\
\text { efficient appliances }\end{array}$ & $11.5 \%$ & $18.7 \%$ & 5.20 & 1.492 & 5.06 & 1.731 & -0.315 & 0.752 & 0.09 \\
\hline $\begin{array}{l}\text { I don't have enough } \\
\text { information about how } \\
\text { replacing my current } \\
\text { appliances with more energy- } \\
\text { efficient ones would contribute } \\
\text { to climate protection }\end{array}$ & $7.3 \%$ & $11.8 \%$ & 4.88 & 1.638 & 5.12 & 1.694 & -1.121 & 0.262 & -0.14 \\
\hline $\begin{array}{l}\text { I feel a certain connection to } \\
\text { my current appliances (loss of } \\
\text { satisfaction) }\end{array}$ & $6.3 \%$ & $10.2 \%$ & 5.03 & 1.457 & 5.10 & 1.713 & -0.481 & 0.630 & -0.04 \\
\hline $\begin{array}{l}\text { expended energy demands } \\
\text { (effort required) }\end{array}$ & $6.1 \%$ & $9.9 \%$ & 4.63 & 1.484 & 5.13 & 1.701 & -2.103 & 0.035 & -0.30 \\
\hline time demands & $5.7 \%$ & $9.2 \%$ & 5.11 & 1.379 & 5.09 & 1.720 & -0.613 & 0.540 & 0.01 \\
\hline $\begin{array}{l}\text { low support and understanding } \\
\text { from my significant others }\end{array}$ & $5.2 \%$ & $8.4 \%$ & 5.27 & 1.367 & 5.07 & 1.716 & -0.299 & 0.765 & 0.11 \\
\hline $\begin{array}{l}\text { I don't consider climate change } \\
\text { to be a sufficient reason to } \\
\text { change my behaviour }\end{array}$ & $1.7 \%$ & $2.7 \%$ & 3.13 & 2.244 & 5.15 & 1.634 & -2.581 & 0.010 & -1.23 \\
\hline health reasons & / & / & / & / & 5.09 & 1.686 & / & / & / \\
\hline $\begin{array}{l}\text { I have the most energy } \\
\text { efficient (or the latest types of) } \\
\text { appliances in my household }\end{array}$ & $38.4 \%$ & / & / & / & / & / & / & / & / \\
\hline
\end{tabular}

Note: First two columns represent shares of positive answers when the reported non-participation in the respective behaviour is included or excluded from the base. In bold are cited significant values $-\mathrm{p}=0.05$.

From all the examined behaviours, individual Greenpeace donors reported the highest average for their willingness to acquire more energy-efficient household appliances. However, the results regarding this particular behaviour do not clearly indicate which of the barriers should be targeted in a public education campaign. There are two barriers that are statistically 
significant. While expended energy demands are a barrier for $6.1 \%$, the difference between this segment and the rest of the respondents, as expressed by Cohen's D, is not very significant. But Cohen's D shows a high value with the barrier related to the respondents' opinion that climate change is not a sufficient reason to change their behaviour - though this barrier was reported by only $1.7 \%$ of the respondents.

As many as $37.9 \%$ of the respondents identified financial demands as a barrier, $24.0 \%$ think that in this case they are doing enough, and $11.5 \%$ do not have enough practical information about how to find and choose more energy-efficient household appliances. Even though these barriers are frequent, our findings suggest that they have almost no influence on the reported willingness to acquire these appliances.

\section{Recycling More Types of Waste}

Table 13: Barriers and the willingness to consider recycling more types of waste

\begin{tabular}{|c|c|c|c|c|c|c|c|c|c|}
\hline \multirow{2}{*}{$\begin{array}{l}\text { What prevents you from } \\
\text { recycling more types of waste } \\
\text { than you have so far? [1=Yes; } \\
0=\text { No] }\end{array}$} & \multirow{2}{*}{$\begin{array}{l}\mathrm{N}=504 \\
\text { Share } \\
\text { (Yes) }\end{array}$} & \multirow{2}{*}{$\begin{array}{l}\mathrm{N}=306 \\
\text { Share } \\
\text { (Yes) }\end{array}$} & \multicolumn{2}{|c|}{ Yes } & \multicolumn{2}{|c|}{ No } & \multicolumn{3}{|c|}{ Mann-Whitney U } \\
\hline & & & Mean & $\begin{array}{l}\text { Std. } \\
\text { Dev. }\end{array}$ & Mean & $\begin{array}{l}\text { Std. } \\
\text { Dev. }\end{array}$ & Z & $\begin{array}{l}\text { As. Sig. } \\
\text { (2-tailed) }\end{array}$ & $\begin{array}{l}\text { Effect } \\
\text { Size } \\
\text { (d) }\end{array}$ \\
\hline $\begin{array}{l}\text { I think that in this case l'm doing } \\
\text { enough for climate protection }\end{array}$ & $31.1 \%$ & $51.3 \%$ & 5.22 & 1.807 & 5.25 & 1.555 & -0.514 & 0.607 & -0.02 \\
\hline $\begin{array}{l}\text { I don't have enough practical } \\
\text { information about how to } \\
\text { recycle more types of waste }\end{array}$ & $25.4 \%$ & $41.9 \%$ & 5.22 & 1.631 & 5.25 & 1.730 & -0.447 & 0.655 & -0.02 \\
\hline time demands & $13.4 \%$ & $22.0 \%$ & 4.84 & 1.669 & 5.35 & 1.677 & -2.450 & 0.014 & -0.30 \\
\hline $\begin{array}{l}\text { expended energy demands } \\
\text { (effort required) }\end{array}$ & $11.8 \%$ & $19.4 \%$ & 4.97 & 1.617 & 5.30 & 1.699 & -1.635 & 0.102 & -0.20 \\
\hline $\begin{array}{l}\text { low support and understanding } \\
\text { from my significant others }\end{array}$ & $8.0 \%$ & $13.2 \%$ & 5.33 & 1.473 & 5.22 & 1.718 & -0.167 & 0.867 & 0.06 \\
\hline $\begin{array}{l}\text { I don't have enough information } \\
\text { about how recycling more types } \\
\text { of waste would contribute to } \\
\text { climate protection }\end{array}$ & $3.2 \%$ & $5.3 \%$ & 4.41 & 2.315 & 5.29 & 1.632 & -1.061 & 0.289 & -0.53 \\
\hline financial demands & $0.6 \%$ & $1.0 \%$ & 4.52 & 3.320 & 5.16 & 1.857 & -0.037 & 0.971 & -0.34 \\
\hline $\begin{array}{l}\text { I don't consider climate change } \\
\text { to be a sufficient reason to } \\
\text { change my behaviour }\end{array}$ & $0.5 \%$ & $0.8 \%$ & 3.15 & 2.585 & 5.25 & 1.670 & -1.522 & 0.128 & -1.26 \\
\hline health reasons & $0.4 \%$ & $0.6 \%$ & 1.00 & 0.000 & 5.25 & 1.667 & -1.686 & 0.092 & -2.55 \\
\hline $\begin{array}{l}\text { It's not possible to recycle any } \\
\text { more waste than I am recycling } \\
\text { (paper, plastic, glass, organic } \\
\text { waste, fabric, medicines, batteries, } \\
\text { electrical appliances, aluminum, } \\
\text { metal ... ) }\end{array}$ & $39.3 \%$ & / & / & / & / & I & I & I & / \\
\hline
\end{tabular}

Note: First two columns represent shares of positive answers when the reported non-participation in the respective behaviour is included or excluded from the base. In bold are cited significant values $-\mathrm{p}=0.05$. 
Greenpeace donors have reported a strong willingness to recycle more types of waste, but the barriers they have marked do not clearly indicate which of the barriers should be targeted in a public education campaign. Specifically, the summary of the barriers related to the willingness to recycle more types of waste shows that with most of the reported barriers there is not a significant difference in the willingness to recycle more between those respondents who perceive the particular barriers and those who do not perceive them. There is only one barrier that shows a significant difference between these two groups-time demands, which represent a barrier for $13.4 \%$ of the respondents. Recycling does demand time, and thus this barrier cannot be removed by a public education campaign. However, it could be lowered by improving the availability of recycling bins for various types of waste.

\section{Lowering Room Temperature}

Table 14: Barriers and the willingness to lower the room temperature in one's household

\begin{tabular}{|c|c|c|c|c|c|c|c|c|c|}
\hline \multirow{2}{*}{$\begin{array}{l}\text { What prevents you from } \\
\text { keeping the room temperature } \\
\text { in your household in winter at } \\
\left.20^{\circ} \mathrm{C} \text { (or lower)? [ } 1=\text { Yes; } 0=\mathrm{No}\right]\end{array}$} & \multirow{2}{*}{$\begin{array}{l}\mathrm{N}=504 \\
\text { Share } \\
\text { (Yes) }\end{array}$} & \multirow{2}{*}{$\begin{array}{l}\mathrm{N}=290 \\
\text { Share } \\
\text { (Yes) }\end{array}$} & \multicolumn{2}{|c|}{ Yes } & \multicolumn{2}{|c|}{ No } & \multicolumn{3}{|c|}{ Mann-Whitney U } \\
\hline & & & Mean & $\begin{array}{l}\text { Std. } \\
\text { Dev. }\end{array}$ & Mean & $\begin{array}{l}\text { Std. } \\
\text { Dev. }\end{array}$ & Z & $\begin{array}{l}\text { As. Sig. } \\
\text { (2-tailed) }\end{array}$ & $\begin{array}{l}\text { Effect } \\
\text { Size } \\
\text { (d) }\end{array}$ \\
\hline $\begin{array}{l}\text { I like the current temperature } \\
\text { (loss of satisfaction) }\end{array}$ & $33.4 \%$ & $58.2 \%$ & 2.73 & 1.575 & 4.20 & 2.053 & -5.585 & 0.000 & -0.77 \\
\hline health reasons & $17.1 \%$ & $29.8 \%$ & 2.55 & 1.656 & 3.63 & 1.925 & -4.291 & 0.000 & -0.58 \\
\hline $\begin{array}{l}\text { low support and understanding } \\
\text { from my significant others }\end{array}$ & $13.5 \%$ & $23.6 \%$ & 3.61 & 1.873 & 3.19 & 1.914 & -1.781 & 0.075 & 0.22 \\
\hline $\begin{array}{l}\text { I think that in this case I'm doing } \\
\text { enough for climate protection }\end{array}$ & $11.9 \%$ & $20.8 \%$ & 4.55 & 1.929 & 2.98 & 1.774 & -5.027 & 0.000 & 0.88 \\
\hline $\begin{array}{l}\text { I don't have enough practical } \\
\text { information about what that } \\
\text { would mean at my place - how } \\
\text { we should prepare for lowering } \\
\text { the temperature to } 20^{\circ} \mathrm{C}\end{array}$ & $7.4 \%$ & $12.9 \%$ & 3.48 & 1.795 & 3.26 & 1.926 & -0.572 & 0.567 & 0.11 \\
\hline $\begin{array}{l}\text { I don't have enough } \\
\text { information about how lowering } \\
\text { the temperature to } 20^{\circ} \mathrm{C} \text { would } \\
\text { contribute to climate protection }\end{array}$ & $7.4 \%$ & $12.9 \%$ & 3.12 & 1.663 & 3.31 & 1.943 & -0.424 & 0.672 & -0.10 \\
\hline $\begin{array}{l}\text { I don't consider climate change } \\
\text { to be a sufficient reason } \\
\text { to change my behaviour }\end{array}$ & $1.5 \%$ & $2.6 \%$ & 1.10 & 0.327 & 3.35 & 1.899 & -3.371 & 0.001 & -1.19 \\
\hline $\begin{array}{l}\text { expended energy demands } \\
\text { (effort required) }\end{array}$ & $1.3 \%$ & $2.3 \%$ & 2.87 & 1.730 & 3.30 & 1.915 & -0.470 & 0.638 & -0.22 \\
\hline financial demands & $1.0 \%$ & $1.7 \%$ & 3.90 & 2.337 & 0.00 & 1.904 & -0.964 & 0.335 & 2.05 \\
\hline time demands & $0.9 \%$ & $1.5 \%$ & 2.99 & 1.414 & 3.30 & 1.918 & -0.175 & 0.851 & -0.16 \\
\hline $\begin{array}{l}\text { In my household the room } \\
\text { temperature in winter is kept at } \\
20^{\circ} \mathrm{C} \text { or lower }\end{array}$ & $42.6 \%$ & / & / & / & / & / & / & / & / \\
\hline
\end{tabular}

Note: First two columns represent shares of positive answers when the reported non-participation in the respective behaviour is included or excluded from the base. In bold are cited significant values $-\mathrm{p}=0.05$. 
The largest proportion of the respondents reported that they are reluctant to lower the room temperature at home to $20^{\circ} \mathrm{C}$ or lower due to loss of satisfaction. The $33.4 \%$ who perceive this barrier are also much less willing to consider changing their behaviour. The $17.1 \%$ who have marked health reasons and the $1.5 \%$ who do not consider climate change to be a sufficient reason to change their behaviour are also not very willing to make a behavioural change. On the other hand, the $11.9 \%$ who think that in this case they are doing enough for climate protection are more willing to change their behaviour. Therefore, when dealing with this barrier in a public education campaign, it could be effective to provide the target group with information about how a warmer house is connected to greenhouse gas emissions. The campaign also could offer inspirational examples of people who are ahead of the target group in lowering the room temperature at home. Communication focused on the positive health effects of lower room temperatures and on the health benefits of hardiness also has the potential to reach people in this target group.

\section{Minimizing Plane Travel}

Table 15: Barriers and the willingness to minimize plane travel in one's free time

\begin{tabular}{|c|c|c|c|c|c|c|c|c|c|}
\hline \multirow{2}{*}{$\begin{array}{l}\text { What prevents you from minimizing } \\
\text { plane travel in your free time? } \\
{[1=\text { Yes; } 0=\mathrm{No}]}\end{array}$} & \multirow{2}{*}{$\begin{array}{l}N=504 \\
\text { Share } \\
\text { (Yes) }\end{array}$} & \multirow{2}{*}{$\begin{array}{l}\mathrm{N}=162 \\
\text { Share } \\
\text { (Yes) }\end{array}$} & \multicolumn{2}{|c|}{ Yes } & \multicolumn{2}{|c|}{ No } & \multicolumn{3}{|c|}{ Mann-Whitney U } \\
\hline & & & Mean & $\begin{array}{l}\text { Std. } \\
\text { Dev. }\end{array}$ & Mean & $\begin{array}{l}\text { Std. } \\
\text { Dev. }\end{array}$ & Z & $\begin{array}{l}\text { As. Sig. } \\
\text { (2-tailed) }\end{array}$ & $\begin{array}{l}\text { Effect } \\
\text { Size } \\
\text { (d) }\end{array}$ \\
\hline time demands & $14.8 \%$ & $46.1 \%$ & 4.00 & 1.708 & 4.07 & 2.342 & -0.641 & 0.521 & -0.03 \\
\hline $\begin{array}{l}\text { I like plane travel / with no plane } \\
\text { travel I'd have to give up traveling } \\
\text { to places that are important to me } \\
\text { (loss of satisfaction) }\end{array}$ & $13.6 \%$ & $42.6 \%$ & 3.30 & 1.889 & 4.70 & 1.964 & -4.160 & 0.000 & -0.72 \\
\hline $\begin{array}{l}\text { I think that in this case l'm doing } \\
\text { enough for climate protection }\end{array}$ & $10.7 \%$ & $33.3 \%$ & 5.11 & 2.034 & 3.58 & 1.883 & -4.269 & 0.000 & 0.81 \\
\hline financial demands & $4.7 \%$ & $14.7 \%$ & 3.88 & 1.904 & 4.06 & 2.076 & -0.419 & 0.675 & -0.09 \\
\hline $\begin{array}{l}\text { expended energy demands (effort } \\
\text { required) }\end{array}$ & $4.2 \%$ & $13.0 \%$ & 3.43 & 1.750 & 4.14 & 2.083 & -1.460 & 0.144 & -0.34 \\
\hline $\begin{array}{l}\text { I don't consider climate change to } \\
\text { be a sufficient reason to change } \\
\text { my behaviour }\end{array}$ & $1.4 \%$ & $4.4 \%$ & 2.36 & 2.488 & 4.12 & 1.991 & -2.099 & 0.036 & -0.88 \\
\hline $\begin{array}{l}\text { I don't have enough information } \\
\text { about how minimizing plane } \\
\text { travel would contribute to climate } \\
\text { protection }\end{array}$ & $1.3 \%$ & $4.0 \%$ & 2.48 & 1.393 & 4.11 & 2.046 & -1.935 & 0.053 & -0.80 \\
\hline $\begin{array}{l}\text { I don't have enough practical } \\
\text { information about alternative forms } \\
\text { of travel }\end{array}$ & $1.2 \%$ & $3.9 \%$ & 2.43 & 1.531 & 4.09 & 2.043 & -1.866 & 0.062 & -0.82 \\
\hline $\begin{array}{l}\text { low support and understanding } \\
\text { from my significant others }\end{array}$ & $1.1 \%$ & $3.5 \%$ & 3.74 & 2.911 & 4.04 & 2.030 & -0.019 & 0.985 & -0.15 \\
\hline health reasons & $0.8 \%$ & $2.6 \%$ & 3.51 & 1.875 & 4.05 & 2.056 & -0.537 & 0.591 & -0.26 \\
\hline I don't travel by plane in my free time & $68.0 \%$ & / & / & / & / & / & / & / & / \\
\hline
\end{tabular}

Note: First two columns represent shares of positive answers when the reported non-participation in the respective behaviour is included or excluded from the base. In bold are cited significant values $-\mathrm{p}=0.05$. 
In the area of minimizing plane travel, there are significant differences among Greenpeace donors in three of the barriers. Those who experience a loss of satisfaction in regards to minimizing plane travel $(13.6 \%)$ and those few who do not consider climate change to be a sufficient reason to change their behaviour (1.4\%) are less willing to change their behaviour. On average, the $10.7 \%$ who think that in this case they are doing enough are more willing to make a behavioural change. A significant proportion of the respondents $(14.8 \%)$ also reported time demands as a barrier, but this group does not indicate a lower willingness to minimize plane travel. Here a suitable strategy for a public education campaign would be to familiarize the target group with interesting people who do consider climate change to be a sufficient reason to change their behaviour. In this respect they are ahead of the target group. They actively search for alternatives to flying, and at the same time find these alternative modes of travel satisfying.

\section{Limiting Short-Distance Car Travel}

Table 16: Barriers and the willingness to consider limiting short-distance commuting by car

\begin{tabular}{|c|c|c|c|c|c|c|c|c|c|}
\hline & $N=504$ & $\mathrm{~N}=\mathbf{2 8 0}$ & & & & & & nn-Whitney & \\
\hline $\begin{array}{l}\text { What prevents you from limiting } \\
\text { short-distance commuting by } \\
\text { car (up to } 15 \mathrm{~km}) \text { ? [ } 1=\text { Yes; } 0=\mathrm{No}]\end{array}$ & $\begin{array}{l}\text { Share } \\
\text { (Yes) }\end{array}$ & $\begin{array}{l}\text { Share } \\
\text { (Yes) }\end{array}$ & Mean & $\begin{array}{l}\text { Std. } \\
\text { Dev. }\end{array}$ & Mean & $\begin{array}{l}\text { Std. } \\
\text { Dev. }\end{array}$ & Z & $\begin{array}{l}\text { As. Sig. } \\
\text { (2-tailed) }\end{array}$ & $\begin{array}{l}\text { Effect } \\
\text { Size } \\
\text { (d) }\end{array}$ \\
\hline time demands & $34.0 \%$ & $61.2 \%$ & 3.82 & 2.022 & 4.64 & 2.003 & -3.092 & 0.002 & -0.41 \\
\hline $\begin{array}{l}\text { I think that in this case l'm doing } \\
\text { enough for climate protection }\end{array}$ & $18.8 \%$ & $33.9 \%$ & 4.82 & 1.994 & 3.80 & 2.020 & -3.637 & 0.000 & 0.51 \\
\hline $\begin{array}{l}\text { expended energy demands } \\
\text { (effort required) }\end{array}$ & $15.4 \%$ & $27.7 \%$ & 3.39 & 1.888 & 4.41 & 2.042 & -3.803 & 0.000 & -0.51 \\
\hline $\begin{array}{l}\text { I like short-distance commuting } \\
\text { by car (loss of satisfaction) }\end{array}$ & $6.0 \%$ & $10.9 \%$ & 3.34 & 1.896 & 4.22 & 2.050 & -2.253 & 0.024 & -0.43 \\
\hline $\begin{array}{l}\text { low support and understanding } \\
\text { from my significant others }\end{array}$ & $4.3 \%$ & $7.8 \%$ & 4.02 & 2.297 & 4.12 & 2.023 & -0.321 & 0.748 & -0.05 \\
\hline financial demands & $4.0 \%$ & $7.2 \%$ & 3.39 & 1.774 & 4.17 & 2.061 & -1.542 & 0.123 & -0.38 \\
\hline health reasons & $3.8 \%$ & $6.8 \%$ & 4.42 & 2.286 & 4.09 & 2.035 & -0.727 & 0.467 & 0.16 \\
\hline $\begin{array}{l}\text { I don't have enough practical } \\
\text { information about how to deal } \\
\text { with short-distance commuting } \\
\text { without a car }\end{array}$ & $3.4 \%$ & $6.1 \%$ & 3.62 & 2.193 & 4.14 & 2.040 & -0.993 & 0.321 & -0.25 \\
\hline $\begin{array}{l}\text { I don't consider climate change } \\
\text { to be a sufficient reason to } \\
\text { change my behaviour }\end{array}$ & $1.3 \%$ & $2.4 \%$ & 2.45 & 2.281 & 4.16 & 2.027 & -1.857 & 0.063 & -0.85 \\
\hline $\begin{array}{l}\text { I don't have enough information } \\
\text { about how limiting short-distance } \\
\text { commuting by car would } \\
\text { contribute to climate protection }\end{array}$ & $0.6 \%$ & $1.0 \%$ & 4.00 & 2.834 & 4.11 & 2.046 & -0.057 & 0.954 & -0.05 \\
\hline $\begin{array}{l}\text { I don't commute short-distance } \\
\text { by car }\end{array}$ & $44.5 \%$ & I & / & / & / & / & / & / & I \\
\hline
\end{tabular}

Note: First two columns represent shares of positive answers when the reported non-participation in the respective behaviour is included or excluded from the base. In bold are cited significant values $-\mathrm{p}=0.05$. 
Those respondents who perceive a major barrier to be time demands (34.0 \%), expended energy demands $(15.4 \%)$, and loss of satisfaction $(6.0 \%)$ are significantly less willing to consider limiting short distance car travel. On the other hand, those respondents who think that in this case they are doing enough (18.8\%) are more willing to change their behaviour. These barriers are difficult for a campaign to overcome. In order to decrease their influence, it would be more effective to emphasize the benefits of alternative behaviours, for example walking or bicycling (recreation, health benefits, etc.). Further, especially in urban areas where more environmentally-friendly alternatives may actually involve saving time, it would be advisable to stress the alternatives' time efficiency.

\section{Discussion}

In accordance with models of pro-environmental behaviour (Ajzen 1991; Stern 2000), the above analysis of barriers to climate-friendly behaviour shows that having pro-environmental attitudes is not sufficient for people to get involved in pro-environmental behaviour. The presented results have confirmed this: even the pro-environmentally oriented respondents demonstrate considerable reserves in their pro-environmental behaviour because, apart from their attitudes, their willingness to participate in this behaviour is influenced by many other factors (see the overview in Clayton and Myers 2009: 145-156; Krajhanzl, Zahradníková and Rut 2009: 10-18; Steg, van den Berg and de Groot 2013: 129-220, Krajhanzl 2014: 114-136). Therefore, it cannot be assumed that the inclination toward pro-environmental attitudes is a guarantee of the target group's pro-environmental behaviour (Gardner and Stern 1996: 71-94).

Our study also pinpoints the possibilities of the Community-Based Social Marketing (McKenzie-Mohr and Smith 1999; McKenzie-Mohr 2011) approach which identifies barriers to specific behaviours among specific target groups. As the results of our study show, the composition of barriers to particular behaviours differs significantly from behaviour to behaviour. Therefore, when planning public education campaigns requires identifying as precisely as possible the barriers to a specific behaviour of a specific target group (Tyson 2009: 29-36; Lee and Kotler 2011: 185-211), the Community-Based Social Marketing approach offers a suitable strategy. In addition, we have explored the limits of mapping barriers as conducted according to the Community-Based Social Marketing approach that is based on self-reports. Clearly, these limits are serious: in regards to the willingness to adopt more climate-friendly behaviours, it is only in a minority of the cases that respondents for whom a certain barrier prevented them from adopting a climate-friendly behaviour differ in a statistically significant way from the respondents who did not reported the same barrier. In other words, only a part of the barriers reported by the respondents are linked to a statistically stronger willingness to behave in a more climatefriendly way. Therefore, if we formulated a recommendation for a particular public education campaign solely on the basis of self-reports, as is suggested by the Community-Based Social Marketing approach, this recommendation would differ greatly from the one we would formulate after also examining the difference in willingness to change the behaviour between the groups with a present and an absent barrier (conducted by the Mann Whitney U test and Cohen's D).

The present study has several limitations. The results are based on data collected from 504 respondents from among former and current Greenpeace donors who were contacted 
by email. Since the participation in the research was voluntary, the sample of the population was self-selected. Nevertheless, our analysis has shown that the socio-demographic variables of the sample correspond to a high degree to those of the whole population of Czech Greenpeace donors. Moreover, to address the composition of the sample in relation to the surveyed population as part of the data preparation process, the data were weighted. On the other hand, it is not clear whether the donors who decided to respond to our request and take part in the research may differ from the other donors specifically in the area of their climate-relevant attitudes and behaviours. Even though it is hard to imagine a type of data collection among this population that would be based on something other than voluntary participation (and thus self-selecting), when interpreting these results it is still necessary to keep in mind the possible limits of the sample's representativeness.

In addition, our study has also supported the notion that with some of the questions, selfreports are not very reliable (Babbie 2010: 261). While the interpretation of the responses regarding the various barriers could be corrected with the help of additional analyses, using the Mann-Whitney U test and Cohen's D, in other areas such a correction was not possible. This particularly concerns the question about whether the respondents are already behaving in an environmentally-friendly way. If $68 \%$ of the respondents reported that they do not travel by plane in their free time, $42.6 \%$ keep the room temperature in their household in winter at $20^{\circ} \mathrm{C}$ or lower, and $38.4 \%$ use the most energy-efficient household appliances available, it is important not to overestimate the reliability of these responses. Even though the reliability of the reported proportions can be sometimes questioned, the results still allow us to mutually compare the respective behaviours and the barriers unaffected by these biases. For the purposes of future research, it would be advisable to prepare questions that elicit less social desirability or possibly to use lie scores and the filtering of respondents with an aboveaverage agreement with highly socially-desirable questions.

It was in fact the large proportion of respondents who had reported already doing all they could in a particular behavioural area that posed a certain statistical problem to us. We did not include these respondents' answers to the question related to their willingness to change their behaviour, and in many instances this lead to a significant decrease in the sample size left to compare the presence and absence of a particular barrier. The statistical analyses regarding the barriers that were relevant for only a small percentage of the respondents thus may be based on the answers of just a few respondents. If the barrier was revealed to be significant in spite of these limitations, such a finding may indicate a really large difference that, in a survey based on a bigger sample, might have been revealed to be even more significant. At the same time, it is possible that due to the low overall number of respondents who reported barriers with low frequencies, we were not able to detect a significant difference regarding these questions, even though in a bigger sample it may have been detectable. Therefore, our study offers a basis for more detailed research in this area.

\section{Conclusion}

Climate-friendly household behaviour is an important part of a broad spectrum of climateprotection efforts. This study focused on examining the barriers that interfere with the 
climate-friendly behaviours of a particular pro-environmentally oriented segment of the Czech society - the current and former donors of Greenpeace Czech Republic. The presented analysis showed the most frequent barriers to the seven selected climate-friendly behaviours, and it pinpointed which of the barriers are significant for each particular behaviour. The results support the notion that pro-environmental attitudes are not a guarantee of pro-environmental behaviour. They also show that a Community-Based Social Marketing approach is more suitable than general models of pro-environmental behaviour for describing the barriers to specific behaviours of specific target groups. At the same time, it is important to adjust the results that are based on self-reports by employing additional methodological approaches that compensate for social desirability bias.

\section{Acknowledgements}

The authors are grateful for the cooperation of the Czech Greenpeace Office and its donors, particularly to MUDr. Lenka Pipková and Ing. Jitka Nesrstová. Our methodological consultations with PhDr. Jan Činčera, Ph.D. and Mgr. Jan Urban, Ph.D. were of much benefit to the study. Translation of the text into English was provided by Mgr. Kateřina Prajznerová, M.A., Ph.D. Thanks to you all.

\section{References}

AJZEN, Icek. 1991. "The Theory of Planned Behavior.” Organizational Behavior and Human Decision Processes 50(2): 179-211.

BABBIE, Earl. 2010. The Practice of Social Research. Wadsworth: Cengage Learning.

BAKIR, Vian. 2005. "Greenpeace v. Shell: Media Exploitation and the Social Amplification of Risk Framework (SARF).” Journal of Risk Research 8(7-8): 679-691.

BAMBERG, Sebastian and Guido MÖSER. 2007. "Twenty years after Hines, Hungerford, and Tomera: A new meta-analysis of psycho-social determinants of pro-environmental behaviour." Journal of Environmental Psychology 27(1): 14-25.

BERGENGREN, Jon C., Duane E. WALISER and Yuk L. YUNG. 2011. "Ecological sensitivity: a biospheric view of climate change." Climatic Change 107(3-4): 433-457.

BOSTROM, Ann, Gisela BÖHM and Robert E. O'CONNOR. 2013. "Targeting and Tailoring Climate Change Communications." WIREs Climate Change. 4(5): 447-455.

BRUNI, Coral M. and P. Wesley SCHULTZ. 2010. "Implicit beliefs about self and nature: Evidence from an IAT game.” Journal of Environmental Psychology. 30(1): 95-102.

COHEN, Jacob. 2013. Statistical power analysis for the behavioral sciences. Waltham: Academic Press.

CLAYTON, Susan and Gene MYERS (eds.). 2009. Conservation Psychology: Understanding and Promoting Human Care for Nature. Oxford: Wiley-Blackwell.

ČESKÝ STATISTICKÝ ÚŘAD. 2014. Sčitání lidu, domů a bytů 2011. Český statistický úřad. Veřejná databáze. Retrieved December 20, 2014 (http://vdb.czso.cz/).

CVVM. 2014. Vztah k životnímu prostředi a chování domácností-květen 2014. Retrieved December 20, 2014 (http://cvvm.soc.cas.cz/media/com_form2content/documents/c1/a7251/f3/oe140616.pdf).

DIETZ, Thomas, Gerald T. GARDNER, Jonathan GILLIGAN, Paul C. STERN and Michael P. VANDENBERGH. 2009. "Household actions can provide a behavioral wedge to rapidly reduce US car- 
bon emissions." Proceedings of the National Academy of Sciences of the United States of America 106(44): 18452-18456.

DIETZ, Thomas, Christina LESHKO and Aaron M. McCRIGHT. 2013. "Politics shapes individual choices about energy efficiency." Proceedings of the National Academy of Sciences of the United States of America 110(23): 9191-9192.

DIETZ, Thomas, Paul C. STERN and Elke U. WEBER. 2013. "Reducing carbon-based energy consumption through changes in household behavior." Daedalus 142(1): 78-89.

DOYLE, Julie. 2007. "Picturing the Clima(c)tic: Greenpeace and the Representational Politics of Climate Change Communication." Science as Culture 16(2): 129-150.

GARCÍA, María M. 2011. "Perception is truth: How U.S. newspapers framed the 'Go Green' conflict between BP and Greenpeace.” Public Relations Review 37(1): 57-59.

GARDNER, Gerald T. and Paul C. STERN. 1996. Environmental Problems and Human Behavior. Boston: Allyn and Bacon.

GEMENNE, François, Jon BARNETT, Neil W. ADGER and Geoffrey D. DABELKO. 2014. "Climate and security: evidence, emerging risks, and a new agenda." Climatic Change 123(1): 1-9.

GREENPEACE ČESKÁ REPUBLIKA. 2014a. Greenpeace Česká republika. Retrieved December 20, 2014 (http://www.greenpeace.org/czech/cz/).

GREENPEACE ČESKÁ REPUBLIKA. 2014b. Výroční zpráva. Greenpeace Česká republika. Retrieved December 20, 2014 (http://www.greenpeace.org/czech/Global/czech/P3/publikace/ Vyrocni\%20zpravy/vyrocni_zprava_12.pdf).

GREENPEACE INTERNATIONAL. 2009. Greenpeace Science Unit. Greenpeace International. Retrieved December 20, 2014 (http://www.greenpeace.org/international/en/about/greenpeace-science-unit-2/).

HEINZ, Bettina, Hsin-I CHENG and Ako INUZUKA. 2007. "Greenpeace Greenspeak: A Transcultural Discourse Analysis." Language and Intercultural Communication 7(1): 16-36.

HUNGERFORD, Harold R. and Trudi L. VOLK. 1990. "Changing Learner Behavior through Environmental Education." The Journal of Environmental Education 21(3): 8-21.

IPPC. 2014. "Summary for Policymakers." Pp. 1-33 in Climate Change 2014: Impacts, Adaptation, and Vulnerability. Part A: Global and Sectoral Aspects. Contribution of Working Group II to the Fifth Assessment Report of the Intergovernmental Panel on Climate Change, edited by FIELD, Christopher B., Vicente R. BARROS et al. New York: Cambridge University Press.

JEHLIČKA, Petr. 2001. “The new subversives - Czech environmentalists after 1989.” Pp. 81-94 in Pink, purple, green: women's, religious, environmental, and gay/lesbian movements in central Europe today, edited by Helena FLAM. Boulder: East European Monographs.

KENT, Jennifer. 2009. "Individualized responsibility: 'If climate protection becomes everyone's responsibility, does it end up being no-one's?'” Cosmopolitan Civil Societies: An Interdisciplinary Journal 1(3): 132-149.

KLÖCKNER, Christian A. 2013. "Comprehensive model of the psychology of environmental behavior A meta-analysis." Global Environmental Change 23(5): 1028-1038.

KRAJHANZL, Jan. 2014. Psychologie vztahu k přirodě a životnímu prostředí. Brno: Lipka \& Masarykova univerzita.

KRAJHANZL, Jan, Šárka ZAHRADNÍKOVÁ and Ondřej RUT. 2010. Možnosti spolupráce s veřejností (nejen) při ochraně životního prostředí. Praha: Zelený kruh.

LEE, Nancy R. and Philip KOTLER. 2011. Social Marketing: Influencing Behaviors for Good. London: SAGE.

LENTH, Russell V. 2001. "Some practical guidelines for effective sample size determination." The American Statistician 55(3): 187-193. 
McKENZIE-MOHR, Doug and William SMITH. 1990. Fostering Sustainable Behavior: An Introduction to Community-Based Social Marketing. Gabriola Island: New Society Publishers.

McKENZIE-MOHR, Doug. 2011. Fostering Sustainable Behavior: An Introduction to CommunityBased Social Marketing. Gabriola Island: New Society Publishers.

McKENZIE-MOHR, Doug, Nancy R. LEE, Wesley SCHULTZ and Philip A. KOTLER. 2012. Social Marketing to Protect the Environment: What Works. London: SAGE.

McKENZIE-MOHR, Doug. 2014. Fostering Sustainable Behavior. Community-Based Social Marketing. Retrieved December 20, 2014 (http://www.cbsm.com/).

MOBLEY, Catherine and William KILBOURNE. 2013. "Gender Differences in Pro-Environmental Intentions: A Cross-National Perspective on the Influence of Self-Enhancement Values and Views on Technology." Sociological Inquiry 83(2): 310-332.

RÖMMELE, Andrea and Hans-Dieter KLINGEMANN. 2002. Public Information Campaigns \& Opinion Research: A Handbook for the Student \& Practitioner. London: SAGE.

RICHARDSON, Katherine et al. 2009. Synthesis Report from Climate Change: Global Risks, Challenges and Decisions. Copenhagen 2009, 10-12 March. Copenhagen: University of Copenhagen. Retrieved October 1, 2014 (http://climatecongress.ku.dk/pdf/synthesisreport).

SCHULTZ, P. Wesley and Jennifer TABANICO. 2007. "Self, Identity, and the Natural Environment: Exploring Implicit Connections with Nature." Journal of Applied Social Psychology 37(6): 1219-1247.

STEG, Linda, Agnes E. VAN DEN BERG and Judith I. M. DE GROOT (eds.). 2013. Environmental Psychology - An Introduction. Chichester: British Psychological Society \& John Wiley.

STEM. 2009. "Dochází ke globálnímu oteplování, myslí si 80 \% Čechů. Příčinou je podle většiny z nich lidská činnost.” STEM. Retrieved December 20, 2014 (http://www.stem.cz/clanek/1894).

STERN, Paul C. 2000. "Toward a coherent theory of environmentally significant behavior." Journal of Social Issues 56(3): 407-424.

STRØMSNES, Kristin, Per SELLE and Gunnar GRENDSTAD. 2009. "Environmentalism between state and local community: why Greenpeace has failed in Norway." Environmental Politics 18(3): 391-407.

TNS OPINION \& SOCIAL. Climate Change. Report. Special Eurobarometer 409 / Wave EB80.2. European Commision. Retrieved December 20, 2014 (http://ec.europa.eu/public_opinion/archives/ebs/ ebs_409_en.pdf).

TYSON, Ben and Mercedes D. HURD. 2009. Social Marketing Environmental Issues. Bloomington: iUniverse.

UN. A/64/350 Climate change and its possible security implications: report of the Secretary-General. pp. 11. United Nations. Retrieved December 5, 2014 (http://www.unhcr.org/543e 73f69.html).

UNIVERSITY OF EXETER. 2010. “Greenpeace Research Laboratories.” Retrieved December 20, 2014 (http://www.greenpeace.to/greenpeace/).

WBGU - Wissenschaftlicher Beirat der Bundesregierung Globale Umweltveränderungen. 2007. Svět v prechodu: Změna klimatu jako bezpečnostní riziko: Shrnutí pro politické činitele. Translated by Hollan, J. from Welt im Wandel: Sicherheitsrisiko Klimawandel. Zusammenfassung für Entscheidungsträger. Berlin: WBGU. Retrieved December 20, 2014 (http://amper.ped.muni.cz/gw/wbgu/ srkw_cz.pdf).

\section{Authors}

Jan Krajhanzl is a social psychologist, conservation psychologist and ecopsychologist. He works at the Department of Environmental Studies, Faculty of Social Studies, Masaryk University. He specializes in the various types of motivation for pro-environmental behaviour, 
environmental communication and the psychological consequences of a decrease in contact with nature. He is the author of the following publications: Dobre utajené emoce a problémy životního prostředí [Well Hidden Emotions and Environmental Problems; 2012] and Psychologie vztahu k prírodě a životnimu prostředí [Psychology of the Relationship toward Nature and the Environment; 2014]. He is the editor of the Czech Website of Ecopsychology (www.ekopsychologie.cz).

Contact: jan.krajhanzl@mail.muni.cz

Jan Skalik is a Ph.D. student at the Department of Environmental Studies, Faculty of Social Studies, Masaryk University. Among his interests is environmental politics, particularly the proenvironmental attitudes and political strategies of Czech politicians. He also participates in several academic projects and initiatives bridging academia and the NGO sector. His participation in the article was possible thanks to the support of the grant MUNI/A/1299/2014 "Current Approaches to the Study of Environmental Phenomena".

Contact: skalik@mail.muni.cz 